\title{
STRUKTUR DAN MAKNA UNDANG-UNDANG SULTAN ADAM PADA MASA KERAJAAN BANJAR KALIMANTAN SELATAN
}

\author{
Rustam Effendi \\ FKIP Universitas Lambung Mangkurat \\ e-mail: rustameffendi@yahoo.co.id
}

\begin{abstract}
Abstrak
Penelitian ini berupaya mendeskripsikan latar belakang kelahiran dan makna yang terkandung dalam Undang-undang Sultan Adam (UUSA). Penelitian dilaksanakan dengan metode hermeneutik dan filologi. Sumber data adalah teks UUSA yang dibuat pada zaman Sultan Adam memerintah Kerajaan Banjar tahun 1825-1857. Hasil penelitian sebagai berikut. Pertama, kelahiran UUSA dilatarbelakangi oleh pertikaian dua mazhab, yakni mazhab ahlusunah waljamaah dan ahlal albidaah. Kedua, makna keseluruhan teks UUSA menunjukkan bahwa: (1) Kerajaan Banjar sebagai kerajaan teokrasi, (2) ulama dan atau organisasi keagamaan sangat berperan dalam pemerintahan, (3) organisasi keagamaan yang sah adalah mazhab Safii, (4) UUSA disusun berdasarkan pikiran ulama Kerajaan Banjar,yakni Haji Djamaloedin, dan (5) UUSA bertujuan untuk menyempurnakan pengalaman agama, pegangan para hakim memutuskan perkara, dan sebagai upaya perlawanan terhadap organisasi keagamaan lain yang tumbuh pada masa itu.
\end{abstract}

Kata kunci: teokrasi, ahlusunah waljamaah, ahlal albidaah, tarikat samaniyah, tarikat wahdatul wujud

\section{THE STRUCTURE AND MEANING OF UNDANG-UNDANG SULTAN ADAM DURING THE ERA OF THE BANJAR KINGDOM, SOUTH KALIMANTAN}

\begin{abstract}
This study aims to describe the backgrounds of the birth and meaning of Undangundang Sultan Adam (UUSA). It employed the hermeneutic method and philology. The data source was the UUSA text written in the era when Sultan Adam reigned over the Banjar Kingdom in 1825-1857. The findings are as follows. First, the birth of UUSA was due to the fight of two sects, i.e. ahlusunah waljamaah and ahlal albidaah. Second, the whole meaning of the UUSA text shows that: (1) the Banjar Kingdom was a theocratic kingdom, (2) ulemas and religious organizations played dominant roles in the government, (3) legal religious organizations were those in the Safii sect, (4) UUSA was written on the basis of the ideas of the ulema of the Banjar Kingdom, namely Haji Djamaloedin, and (5) UUSA aimed to serve as religious experience perfection, a guide for judges to make decisions, and an attempt to counter other religious organizations growing during the era.
\end{abstract}

Keywords: theocracy, ahlusunah waljamaah, ahlal albidaah, samaniyahway, wahdatul wujud way

\section{PENDAHULUAN}

Khazanah sastra tradisional mencakup pelbagai ungkapan kreativitas yang merupakan warisan masa lalu. Kratz (2004) mengemukakan bahwa sastra tradisional tidak hanya berupa warisan yang bersifat fiksi, tetapi juga berupa naskah-naskah yang di dalamnya berisi persoalan yang terkait dengan agama, peraturan perundangan, figh, dan sejarah. Liaw Yock Fang (1993) mengemukakan bahwa undangundang Melayu lama adalah bahan kajian yang penting dalam kaitannya dengan sistem pemerintahan, sistem pentadbiran, dan susunan masyarakat. Tentu saja semua hal itu terkait dengan politik, bu- 
daya, dan masyarakat pada zamannya. Oleh karena itu, nilai dan makna yang diungkapkan di dalamnya dapat dipertimbangkan sebagai nilai-nilai budaya dan kearifan lokal. Hal itu meniscayakan adanya relevansi dan signifikansinya dengan masyarakat sekarang, yakni sebagai semacam sandaran bagi praksis kontekstualisasi kehidupan agar berbagai nilai kehidupan modern dapat dimaknai dan dilaksanakan tanpa menimbulkan konflik di tengah masyarakat.

Salah satu warisan sastra tradisional Banjar yang belum banyak mendapat perhatian peneliti sastra adalah naskah Undang-Undang Sultan Adam (UUSA). Naskah ini terwujud pada masa pemerintahan Sultan Adam al-Watsiq Billah (1785-1857). Di antara peneliti yang sudah menggali naskah UUSA adalah Jamalie (2012) dan Ideham et al. (2003). Akan tetapi, penelitian Jamalie (2012) dan Ideham et al. (2003) masih terbatas pada pengklasifikasian isi pokok UUSA, dan belum sampai pada pemaknaannya.

Menurut Eisenberger, seorang Controleur van Banjarmasin en Marabahan tahun 1936, pada awalnya UUSA ditulis dengan huruf Jawi atau huruf Arab-Melayu. Naskah UUSA yang ditulis dengan huruf Jawi tersebut tidak pernah ditemukan lagi. Naskah yang ada hingga hari ini adalah naskah UUSA yang disimpan dalam arsip Kantor Residen Banjarmasin yang ditulis oleh Tumenggung Soeri Ronggo tahun 1885. Naskah itu dipublikasikan pertama kali dalam majalah Indische Gids tahun 1881, II halaman 119-186 oleh A.M. Joekes, seorang Gubernur Borneo tahun 1891-1894 (Ideham et al., 2003). Naskah UUSA yang diterbitkan oleh A.M. Joekes inilah yang diteliti dalam penelitian ini. Naskah ini tersimpan dalam Museum Lambung Mangkurat Banjarmasin dengan nomor 342.04 bahagian Undang-Undang Kekuasaan dan Fungsi Pemerintah. Dalam bahagian pendahuluan majalah tersebut dikemukakan perihal yang terkait dengan naskah sebagai berikut.
“A.M. Joekes pada tahun 1881 menerbitkan ulasan tentang Hukum Sultan Adam dan telah disampaikan kepada Komisi Hukum Adat di kawasan Barat. Di bawah ini, naskah tersebut dilampirkan. Tentang hal ini, dapat dibaca pada Indische Gids 1881, II, halaman 119-186. Cara menuliskan yang digunakan, disesuaikan dengan ejaan bahasa Melayu Resmi, yaitu ejaan Van Ophujsen; namun, disesuaikan pula dengan bahasa orang Banjar. Catatan-catatan berasal dari Komisi Hukum Adat."

Kelahiran suatu undang-undang selalu dilatarbelakangi oleh tujuan tertentu, yakni berkenaan dengan keinginan penguasa untuk menata kehidupan masyarakat serta agar segala perintahnya selalu dilaksanakan oleh rakyat. Di samping itu, sebuah undang-undang dapat pula menjadi alat penguasa atau raja untuk mematahkan benih-benih perlawanan terhadap dirinya. Bagi penguasa dan rakyat yang mendukungnya, undang-undang itu perlu ditegakkan. Mereka (raja dan rakyat) menganggap bahwa undang-undang itu memiliki nilai atau makna yang positif bagi kehidupan. Dengan undang-undang itu pemerintahan dapat berjalan dengan baik dan kehidupan bermasyarakat berjalan pula dengan tenteram. Persoalannya, faktor apakah yang melatarbelakangi kelahiran UUSA serta makna apa sajakah yang tergambar di dalam keseluruhan struktur naskah UUSA.

\section{METODE}

Penelitian ini menggunakan metode hermeneutika, yakni metode yang berupaya menafsirkan teks untuk memperoleh kesimpulan makna atau nilai yang hakiki. Ricoeur (2012) mengemukakan bahwa tempat pertama yang didiami hermeneutika adalah bahasa dan lebih khusus lagi bahasa tulis. Kaelan (2005) mengemukakan metode hermeneutika relevan untuk 
menafsirkan berbagai gejala, peristiwa, simbol, nilai yang terkandung dalam ungkapan bahasa atau kebudayaan lainnya, yang muncul pada fenomena kehidupan manusia (Kaelan, 2009).

Penafsiran teks memang rumit, namun harus dilakukan karena teks-teks yang ditulis di masa lampau terus ada dan dibaca, sementara para penulisnya dan kaitan historis yang menghasilkan karya-karya tersebut sudah tidak ada. Oleh karena itu, membaca teks-teks semacam itu menjadi tak terpisahkan dengan masalah penafsiran (Newton, 1994). Karya sastra perlu ditafsirkan sebab di satu pihak karya sastra terdiri atas bahasa, di pihak lain, di dalam bahasa banyak makna yang tersembunyi, atau dengan sengaja disembunyikan (Ratna, 2004). Makna dalam sastra tradisional sering terbungkus oleh simbol-simbol yang berkaitan dengan budaya tempatan (bandingkan dengan Mahali \& Saamah, 2013; Hamzah \& Hassan, 2011).

Dalam proses penafsiran, terdapat alur pemahaman yang disebut lingkaran hermeneutik (hermeneutic circle), yakni posisi melingkar dalam gerak pemahaman dari satu bagian teks ke keseluruhan teks dan dari keseluruhan teks ke bagianbagian teks. Dalam posisi serupa itu pemahaman atas satu bagian teks tidak dapat dicapai sepenuhnya tanpa pemahaman atas keseluruhan teks, sementara itu pemahaman atas keseluruhan teks tidak dapat dicapai tanpa pemahaman atas satu bagian teks (Zaidan, Rustapa dan Haniah, 2007). Dalam kaitannya dengan pemahaman tersebut, perspektif filologis juga digunakan karena menurut Kratz (2004), filologi dapat digunakan sebagai alat dan sekaligus sebagai objek pengkajian. Perspektif filologis berkedudukan penting dalam penelitian ini karena UUSA ditulis dalam bahasa Banjar, yakni salah satu bahasa di Kalimantan yang termasuk ke dalam rumpun bahasa Melayu Austronesia (Kawi, 2011), di samping karena penelitian ini berupaya mengungkapkan nilai atau makna yang terkandung dalam naskah tertentu (Kridalaksana, 1993; Sudjiman, 1995; Piah et al., 2006; Hamzah dan Hassan, 2011; Suryani NS, 2012; Mahali dan Saamah, 2013).

\section{HASIL DAN PEMBAHASAN}

Struktur UUSA terdiri atas dua bagian besar, yakni (1) Pendahuluan atau mukadimah, dan (2) Batang Tubuh atau isi undang-undang. Di samping itu, UUSA juga dilengkapi dengan Peraturan Peralihan. Mukadimah UUSA berisi satu paragraf dan batang tubuh UUSA berisi 31 perkara (31 pasal).

\section{Makna Mukadimah UUSA}

Seperti halnya undang-undang zaman sekarang, UUSA dimulai dengan satu paragraf pendahuluan atau paragraf mukadimah. Paragraf mukadimah berisi tujuan penyusunan UUSA. Dalam mukadimah disebutkan bahwa dibuatnya undang-undang ini memiliki tiga tujuan, yakni untuk kesempurnaan agama dan iktikad, untuk menjaga kerukunan sehingga tidak ada perbantahan, dan untuk memudahkan hakim-hakim memutuskan hukuman terhadap orang yang bersalah.

Tujuan pertama mengisyarakan bahwa pada masa dibuatnya UUSA, agama dan iktikad rakyat masih ada yang belum sempurna. Ketidaksempurnaan agama dan iktikad rakyat dimungkinkan karena pada masa sebelum disusun UUSA ada dua orang ulama Banjar yang mengajarkan ilmu tasawuf yang sangat berbeda dengan cara-cara yang dikembangkan oleh ulama kerajaan Syekh Muhammad Arsyad Al-Banjari. Tasawuf yang dimaksud adalah tasauf wahdatul wujud yang dikembangkan oleh dua orang ulama Banjar yang bernama Syekh Muhammad Nafis bin Ideris bin Husein Al-Banjari dan Syekh Abdul Hamid Abulung. Syekh Muhammad Nafis dan Syekh Abdul Hamid Abulung mengajarkan tasawuf Suni yang 
diperluas dengan tasauf Wahdatul Wujud. Wahdatul Wujud adalah tarikat yang mengajarkan bahwa alam (termasuk manusia) adalah satu nafas sehingga tidak dapat dipisah-pisahkan. Alam adalah Tuhan dan Tuhan adalah Alam. Syekh Abdul Hamid Abulung berkata, “Tiada yang maujud melainkan hanyalah Dia. Tiada aku melainkan Dia. Dialah Aku. Dan aku adalah Dia (Ideham et al., 2003).

Tujuan kedua berkaitan juga dengan situasi 'panas' dalam kehidupan bera-gama. Di satu pihak, raja dan Syekh Arsyad Al-Banjari menghendaki mazhab Syafii yang ahlusunah waljamaah sebagai satu-satunya mazhab di dalam kerajaan Banjar dan di pihak lain, ada pula Syekh Muhammad Nafis dan atau Syekh Abdul Hamid Abulung yang mengembangkan mazhab atau aliran yang disebut wahdatul wujud. Iktikad ahlusunah waljamaah yang dimaksudkan adalah agama Islam berdasarkan faham Suni dan tarikat $S a-$ maniyah.

Tujuan ketiga adalah untuk memudahkan hakim-hakim memutuskan hukuman terhadap orang yang bersalah. Hakim Kerajaan Banjar adalah orang yang ditunjuk raja dan orang tersebut harus memahami agama Islam mazhab ahlusunah waljamaah. Pengetahuan para hakim terhadap agama Islam penting karena UUSA yang berisi 31 perkara yang sepenuhnya dijiwai oleh ajaran agama Islam. Jamali (2012) mengemukakan bahwa semangat dan keinginan Sultan Adam membumikan ajaran Islam yang berdasarkan aliran ahlusunah waljamaah begitu mengedepan dalam UUSA.

\section{Makna Batang Tubuh UUSA}

Batang tubuh UUSA dapat dikelompokkan menjadi 6 bagian, yakni: (i) perkara agama dan peribadatan, (ii) perkara hukum tata pemerintahan, (iii) perkara hukum perkawinan, (iv) perkara hukum Acara Peradilan, (v) perkara hukum penguasaan atas tanah, dan (vi) peraturan peralihan.

\section{Perkara Agama dan Peribadatan}

Perkara agama dan peribadatan diatur dalam perkara 1, 2, 3, 20. Perkara 1 berisi perintah kepada semua rakyat agar beriktikad (berkeyakinan) ahlusunah waljamaah. Hal ini sangat penting karena pada masa pemerintahan Sultan Adam berkembang aliran yang oleh ulama kerajaan disebut iktikad ahlal albidaah. Iktikad ini dianggap sesat karena kata bidaah adalah perbuatan ibadah yang tidak mengacu pada Alquran dan Alhadis Rasulullah saw. Ahlusunnah waljamaah berarti pengikut ajaran Islam yang melaksanakan ibadah hanya berdasarkan Alquran dan hadis Rasulullah saw. Iktikad ahlusunnah waljamaah adalah "harga mati" karena hanya iktikad inilah yang dianggap benar dalam agama Islam di kerajaan Banjar. Walaupun demikian, para pengikut aliran yang disebut ahlal albidaah tetap berupaya merebut simpati rakyat dan menyebarkan ajaran-ajarannya.

Perkara 2, berisi empat perintah raja, yakni: (i) perintah kepada tetuha kampung untuk membuat surau, (ii) perintah kepada semua rakyat agar membawa anak-anaknya untuk sembahyang lima waktu berjamaah, (iii) perintah kepada semua rakyat membawa anak-anaknya sembahyang Jumat, dan (iv) perintah kepada semua rakyat agar melaporkan kepada raja apabila ada orang atau kelompok orang yang enggan sembahyang berjamaah dan atau sembahyang Jumat. Semua perintah ini dimaksudkan untuk menangkal ajaran iktikad albidaah. Pengikut aliran yang dituding ahlal albidaah memiliki cara ritual khusus dalam melaksanakan ibadah. Karena itu, mereka membuat tempat-tempat ibadah yang khusus dan tidak mau melaksanakan ibadah (seperti sembahyang) bersama kelompok lain. Dengan demikian, orang yang tidak bersembahyang secara berjamaah menjadi indikasi awal bahwa orang itu mempunyai iktikad atau keyakinan ahlal albidaah. 
Perkara 3 berisi perintah raja kepada semua rakyat agar tidak ada perbantahan atau pertikaian sesama warga. Yang dimaksud perbantahan di sini terutama adalah perbantahan dalam hal keyakinan terhadap iktikad ajaran agama. Pada masa Sultan Adam terjadi perbantahan antara pengikut ahlusunah waljamaah dan iktikad yang diajarkan oleh Syekh Abdul Hamid Ambulung. Perbantahan ini menyebabkan rakyat tidak bisa bersatu. Oleh karena itulah, perbantahan ini harus dihentikan dan diatur melalui undangundang. Undang-undang menghendaki agar semua rakyat hanya mengikuti satu aliran agama yakni ahlusunat waljamaah dan tarikat Samaniyah.

Perkara 20 berisi perintah kepada tetuha kampung untuk menjaga bulan untuk menentukan awal Ramadan (permulaan puasa Ramadan), akhir Ramadan (hari raya Idul Fitri), awal bulan haji (hari raya Haji atau Idul Adha), dan awal bulan Maulud (bulan kelahiran Rasulullah saw). Selanjutnya, tetuha kampung yang melihat bulan diperintahkan pula untuk menyampaikannya lagi kepada hakim dan hakim menyampaikannya pula kepada raja. Dalam menjaga timbulnya bulan, tetuha kampung dibantu oleh warga masyarakat yang ada di kampung. Mereka duduk di pelataran surau atau mesjid atau di tempat-temput terbuka lainnya yang memungkinkan dapat melihat bulan apabila sewaktu-waktu muncul. Hingga sekarang, tradisi melihat bulan tetap saja dilakukan di kampung-kampung, bahkan, salah satu organisasi Islam terbesar di Indonesia, yaitu Nahdhatul Ulama (NU) konsisten menggunakan rukyat (melihat bulan) untuk menentukan awal dan akhir puasa Ramadan.

\section{Perkara Hukum Tata Pemerintahan}

Terdapat 2 perkara yang berhubungan dengan hukum tata pemerintahan, yakni perkara 21 dan 31. Walaupun kedua perkara ini membicarakan masalah hukum tata pemerintahan, nilai-nilai Islami tetap melekat pada perkara-perkara tersebut.

Pada perkara 21 terlihat bahwa tetuha kampung menjadi orang yang ikut berperan dalam tata pemerintahan. Dalam pemerintahan Sultan Adam, sebuah kampung yang aman, damai, merupakan satu tujuan yang dicita-citakan kerajaan. Untuk mencapai tujuan ini, raja mempercayakan sepenuhnya kepada tetuha kampung untuk menjaga kampungnya masing-masing agar selalu aman dan damai.

Tetuha kampung bukanlah aparat kerajaan tetapi adalah orang yang dipercaya oleh raja dalam satu pekerjaan yang dipandang sangat mulia, seperti menjaga keamanan dan kedamaian, menentukan hari-hari besar Islam, dan lain-lain. Pekerjaan ini, walaupun tidak mendapat uang jasa dari raja, tetapi dirasakan oleh para tetuha kampung sebagai penghormatan dari raja yang tidak dapat dinilai dengan uang. Karena itu, mereka melakukan perintah ini dengan ikhlas dan tanpa pamrih. Apabila terjadi masalah, seperti sengketa tanah, pertikaian rumah tangga, terlebih dahulu dibawa ke hadapan tetuha kampung. Dengan cara ini maka banyak masalah kehidupan masyarakat yang dapat diselesaikan secara kekeluargaan tanpa harus diperkarakan di hadapan hakim.

Perkara 31 mengandung dua hal penting, yakni (i) perintah kepada semua pejabat abdi kerajaan, seperti mantri, lalawangan, lurah, dan pambakal untuk tidak mencampuri urusan para hakim, dan (ii) kewajiban rakyat terhadap kerajaan meliputi kewajiban membayar uang nazar, uang baktin, dan gawi poepoe pinta (bekerja sukarela atau gotong royong) untuk kepentingan kerajaan.

Abdi kerajaan yang mengurus tata pemerintahan dimulai dengan Lalawangan. Lalawangan adalah abdi kerajaan yang memerintah kawasan yang luas yang di masa sekarang dapat disebut distrik. 
Pada umumnya lalawangan adalah mantri. Mantri adalah orang yang mendapat gelar kehormatan dari raja karena jasanya yang luar biasa. Abdi kerajaan di bawah Lalawangan adalah Lurah. Lurah adalah seorang yang mendapat tugas melaksanakan tata pemerintahan yang meliputi beberapa kampung. Setiap kampung dipimpin oleh seorang Pambakal. Dalam melaksanakan tugasnya, lurah dibantu oleh Khalifah, Bilal, dan Kaum.

Dalam perkara 31 ini diatur juga tentang tiga macam kewajiban yang dibebankan kepada setiap rakyat. Tiga kewajiban itu adalah membayar uang nazar, membayar uang baktin, dan melaksanakan gawi dan poepoe pinta. Nazar biasanya dilakukan oleh orang yang tergolong kaya dan untuk menghindari pekerjaan gawi poepoe pinta. Gawi poepoe pinta adalah kewajiban setiap rakyat untuk melaksanakan pekerjaan yang tulus ikhlas untuk kerajaan dan tanpa mengharapkan upah. Di samping gawi poepoe pinta rakyat juga diwajibkan membayar uang baktin. Uang baktin dapat dibayar dengan tenaga atau melakukan sesuatu pekerjaan untuk kepentingan kerajaan.

Dijelaskan juga bahwa nazar baru sah apabila secara tegas diucapkan dihadapan seorang saksi. Saksi yang sah adalah seorang abdi kerajaan seperti Lalawangan. Jadi, ada tiga syarat nazar yang sah, yakni diucapkan secara tegas di hadapan saksi, menyebutkan berapa jumlah uang nazar, dan menyebutkan alasan mengapa atau untuk apa nazar itu diucapkan. Alasan itu di antaranya adalah untuk menghindari gawi poepoe pinta dan atau untuk ketentraman dan keamanan harta benda. Apabila nazar tidak sah karena kekurangan syarat maka seseorang itu tetap dikenakan pekerjaan gawi poepoe pinta. UUSA memberikan contoh ucapan nazar yang sah sebagai berikut, "... adapoen nadzar jang sah jang djadi halal pembajarannja itoe bahwa berkata kata ia tiap tiap saorang lamoen oeloen tiada dikanai gawi poepoe pinta dan tiada dihaoer biroe milik oeloen wadjib atas oeloen bernadzar maatoeri pada tiap tiap moesim doea rial setali... (... adapun nazar yang sah yang halal pembayarannya itu bahwa berkata-kata seseorang kalau saya tidak dikenakan gawi pupu pinta dan tidak diharu-biru milik saya maka wajib bagi saya membayar nazar setiap musim dua rial setali).

Raja dan rakyat mempunyai keyakinan yang sama bahwa undang-undang ini dibuat bukan sekedar kehendak raja tetapi merupakan hukum Allah. Karena itu, semua rakyat dan abdi kerajaan wajib melaksakan semua perintah yang dituliskan dalam undang-undang. Akhir dari perkara 31 menyebutkan "... hakim hakim dan lalawangan loerah mantrinja kalau ada jang anggan dan tiada maasi hoekoem Allah jang dihoekoemkan oleh hakim jaitoe sekalian lalawangan dan loerahnja dan mantrinja koesoeroeh mangaraskan hoekoem itu (“... hakim-hakim dan lalawangan, lurah, dan mantrinya, kalau ada yang enggan dan tidak mau menurut hukum Allah yang dihukumkan oleh hakim maka sekalian lalawangan dan lurahnya dan mantrinya kusuruh menguatkan hukumnya itu).

\section{Perkara Hukum Perkawinan}

Ada 6 buah perkara yang berhubungan dengan hukum perkawinan, yakni perkara 4, 5, 6, 18, 25, dan 30 .

Menurut perkara 4, pernikahan dianggap sah apabila ada dua orang yang dianggap adil sebagai saksi pernikahan. Pernikahan dipimpin oleh seorang hakim. Saksi yang adil adalah saksi yang mengatakan sebenarnya tentang status orang yang dikawinkan, seperti perawan atau janda. Begitu juga tentang status calon pengantin lelaki, apakah jejaka atau duda, apa pekerjaannya yang sebenarnya, dan lain-lain.

Pernikahan dipimpin oleh seorang hakim agama yang ditunjuk oleh raja. Dengan demikian, hakim yang ditunjuk harus memiliki syarat yang cukup. Syarat 
itu di antaranya adalah pengetahuan tentang hukum perkawinan dan yang lebih penting adalah hakim yang loyal terhadap raja dan tradisi iktikad ahlusunah waljamaah. Saksi adalah orang yang juga banyak mengetahui tentang hukum perkawinan. Saksi dapat meminta kepada hakim agar mengulang sekali lagi katakata ijab (kuterima menikahi si Pulan bin si Pulan dengan maharnya...) apabila saksi memandang kurang cepat, kurang jelas, atau kurang lengkap.

Perkara 5 berisi ketentuan bahwa mazhab Syafii merupakan satu-satunya mazhab yang wajib diikuti dan wajib dilaksanakan dalam kegiatan ibadat. Mazhab Syafii dipandang sebagai satu-satunya mazhab yang murni berdasarkan ahlusunah waljamaah. Dalam perkara 5 ini tersirat pula adanya kemungkinan orang melangsungkan pernikahan dengan taklid lain selain mazhab Syafii. Tampaknya Perkara 5 ini menunjuk kepada mazhab yang mereka sebut ahlal albidaah yang dipimpin oleh Abdul Hamid Abulung. Dengan perkara ini, raja mengharapkan kehatihatian para hakim dalam memimpin upacara pernikahan dan sekaligus sebagai upaya membendung berkembangnya mazhab ini ahlal albidaah.

Perkara 6 menyangkut pernikahan yang digugat oleh seorang istri. Karena sesuatu hal (mungkin suami lama meninggalkan atau tidak memberikan nafkah) seorang istri meminta pasahkan nikahnya (minta dibatalkan nikahnya atau meminta bercerai). Hal ini menyiratkan bahwa pembatalan nikah oleh seorang perempuan pernah terjadi dan mungkin akan terjadi lagi. Agar gugatan istri itu sah dan sesuai dengan hukum ahlusunah waljamaah maka UUSA menuliskannya dalam perkara 6. Untuk memutuskan perkara pasah, seorang hakim harus memeriksa ekral (perjanjian) yang telah diucapkan suaminya kepada perempuan itu sewaktu nikah. Ekral itu menjadi dasar hakim dalam memutuskan perkara pembatalan nikah. Jadi, pada waktu nikah, seorang laki-laki tidak hanya membayar jujuran (mahar) tetapi juga mengucapkan janji. Janji-janji yang disebut ekral itu diucapkan di depan istri, hakim, dan saksi-saksi.

Perkara 18 adalah perihal suami istri yang barambangan (berpisah tempat tinggal; (pisah ranjang) karena persoalan rumah tangga. Kata barambangan berarti suami istri itu belum resmi bercerai tetapi baru berpisah tempat tinggal. Biasanya si istri pulang ke rumah orang tuanya dan suami tetap tinggal di rumahnya. Apabila terjadi hal semacam ini maka suami tidak boleh memegang atau bersentuhan dengan istrinya sebelum ada kesepakatan rujuk. Dalam perkara 18 tersurat bahwa raja sangat tidak setuju dengan perceraian. Karena itu, raja memerintahkan kepada hakim dan kerabat dari dua pihak suami istri untuk berunding dan memberi nasihat agar dapat bersatu kembali. Walaupun demikian, apabila ternyata si istri keras tidak mau rujuk, hakim berkewajiban melaporkan hal itu kepada raja dan raja akan memutuskan persoalan itu.

Pada pasal sebelumnya telah disebutkan bahwa seorang yang melaksakan nikah harus membawa dua orang saksi. Saksi tersebut membentangkan pengetahuannya secara jujur tentang wanita yang mau kawin. Dengan dasar ini hukum perkawinan menurut undang-undang sudah sangat kuat. Untuk mencegah fitnah dalam perkawinan, UUSA membuat perkara 25 yang intinya seorang suami tidak boleh menuduh istrinya tidak berdara (tidak perawan atau tidak bujang) tanpa saksi. Menurut UUSA, kesalahan seorang suami yang menuduh istrinya tidak berdara adalah tergolong kesalahan yang besar apalagi isu itu telah dikabarkabarkan ke mana-mana. Apabila persoalan barambangan dapat diselesaikan oleh hakim bersama keluarga suami dan keluarga istri maka dalam hal tuduhan seorang suami kepada istrinya tentang istrinya yang tidak perawan, langsung 
ditangani oleh raja. Mendakwa seorang perempuan tanpa saksi dianggap merendahkan hukum karena sebelum dilaksanakannya perkawinan telah terjadi kesepakatan yang disaksikan oleh dua orang saksi.

Perkara 30 berisi masalah dan hukum berzina. Perbuatan zina merupakan hal yang sangat tidak disukai masyarakat Banjar. Sebagian orang Banjar lebih menyukai mempunyai lebih dari satu istri daripada melakukan zina. Satu orang berzina dianggap merusak nama rakyat satu kampung. Bahkan, jika terjadi bencana kebakaran, kekeringan, buah-buahan tiada menjadi, biasanya ada satu anggapan bahwa semua ini disebabkan adanya orang dalam kampung itu yang berbuat zina. Dampak lebih besar lagi adalah pada anak hasil perzinaan itu. Anak hasil perzinaan disebut anak kampang. Adanya anak kampang ini membuat orang Banjar sangat takut berzina dan ngeri memikirkan dampak bagi keturunan-keturunannya selanjutnya. Dalam perkara ini disebutkan bahwa apabila ada seseorang yang tertangkap tangan melakukan perzinaan namun bersikeras tidak mengakui perbuatannya maka hukuman bagi orang itu akan dijatuhkan langsung oleh raja.

\section{Perkara Hukum Acara Peradilan}

Ada 10 perkara yang membicarakan hukum acara peradilan, yakni perkara 7 , 8, 9, 10, 11, 12, 13, 14, 15, 19, dan 24 .

Perkara 7 menegaskan bahwa walaupun mufti adalah hakim tertinggi namun dia tidak diizinkan mencampuri urusan hakim. Pada masa UUSA, mufti adalah hakim tertinggi yang bertugas mengawasi pengadilan umum (Halidi, 1980). Hanya hakim yang berhak memberi pitoea (memberi nasihat dan memutuskan hukuman) atau memintakan pitoea kepada raja bagi orang yang akan atau yang sedang berperkara. Raja tidak mengizinkan mufti ikut memberi nasihat kepada orang yang akan dan atau yang sedang menjalani perkara hukum.
Pada dasarnya yang berhak memberi pitoea adalah hakim. Namun pada Perkara 8 ada ketentuan bahwa mufti sewaktuwaktu diperbolehkan memberi pitoea apabila ada perintah atau permintaan raja. Walaupun demikian, seseorang mufti harus berhati-hati apabila ada seseorang yang datang yang mengaku disuruh raja meminta pitoea. Dalam perkara 8 UUSA disebutkan bahwa apabila orang tersebut benar disuruh oleh raja maka orang itu harus dapat menunjukkan surat yang bercap kerajaan.

Perkara 9 berisi larangan bagi orang yang menjalani hukuman mendatangi abdi-abdi kerajaan, seperti raja-raja muda, mantri-mantri, pambakal-pambakal, dan panakawan-panakawan. Hal ini dilakukan agar tidak ada tawar-menawar vonis hukuman dan hukum dapat ditegakkan seadil-adilnya.

Pada perkara 10 disebutkan lagi bahwa hakim bertugas memeriksa dengan cermat tuduhan, pembelaan diri dari orang yang tertuduh, serta memeriksa orang-orang yang menjadi saksi dalam suatu perkara. Pada perkara-perkara sebelumnya disebutkan juga bahwa hakim memiliki kekuasaan dalam memutuskan suatu perkara. Dalam pasal ini ditambahkan lagi bahwa raja meminta kepada hakim untuk merundingkan keputusan hukuman itu dengan lurah dan kalifah tempat orang yang dijatuhi hukuman.

Permufakatan antara hakim, lurah, dan kalifah bertujuan agar putusan hukuman tidak hanya dilihat dari sisi hakim tetapi juga dari sisi seorang lurah dan kalifah yang mengetahui banyak tentang warganya yang berperkara di pengadilan. Dengan demikian, keputusan yang dikeluarkan hakim tidak hanya melihat pasal undang-undang tetapi juga melihat latar belakang masalah yang terjadi pada diri seseorang.

Perkara 11 menyebutkan bahwa apabila keputusan perkara sudah ditulis maka surat keputusan itu akan menjadi 
sah setelah diberi cap kerajaan. Hakim tidak memegang cap kerajaan. Cap kerajaan dipegang oleh ading-ading. Yang dimaksud ading-ading adalah adik sultan yang memangku tugas sebagai mangkubumi. Dengan demikian, semua keputusan pengadilan akan tersimpan di dalam arsip mangkubumi.

Perkara 12 berisi ketentuan bahwa keputusan yang dijatuhkan oleh hakim sudah dianggap final dan tidak dapat diganggu gugat lagi. Orang yang tidak menerima hukuman tidak bakal menerima keringanan hukuman tetapi malah hukuman yang telah diputuskan itu akan dikuatkan oleh ading (mangkubumi). Keputusan hukuman yang dibuat oleh hakim sangat dipercaya oleh raja sebagai keputusan yang adil. Hal ini disebabkan seorang hakim yang diangkat oleh raja adalah seorang yang benar-benar memiliki pengalaman dan pengetahuan yang luas tentang seluk beluk hukum, terutama hukum Islam. Di samping itu, seperti disebutkan dalam perkara sebelumnya, keputusan yang diambil harus berdasarkan permufakatan dengan lurah dan kalifah tempat tinggal orang yang dikenakan hukuman.

Perkara 13 berisi perintah raja kepada para bilal dan kaum (petugas kebersihan mesjid) untuk membantu hakim dalam memutuskan perkara apabila diperlukan. Jadi, dalam konsep berpikir masa lalu, bilal dan kaum bukan saja sekedar azan dan membersihkan mesjid atau surau tetapi juga dapat membantu memperjelas duduk persoalan suatu perkara. Sebelum menjatuhkan hukuman, hakim mencari informasi kepada abdi-abdi kerajaan di kawasan orang yang berperkara. Bilal dan kaum harus membantu memberikan informasi tambahan tentang seseorang yang bertempat tinggal yang sama dengan bilal dan kaum. Dengan cara ini, maka hukuman yang dijatuhkan oleh hakim adalah hukuman yang telah dianggap paling tepat.
Perkara 14 memperlihatkan jenjang pengurusan perkara. Suatu perkara hukum harus benar-benar telah diperiksa sebelumnya oleh tetuha kampung. Tetuha kampung terlebih dahulu mengupayakan perdamaian atau permufakatan antara dua pihak yang berperkara. Dua pihak yang berperkara berargumentasi atau berdebat tentang hal yang diperkarakan di depan tetuha kampung. Tetuha kampung dibantu oleh seorang yang bertugas mencatat semua hal yang menjadi kesepakatan dalam pertemuan itu. Apabila upaya permufakatan dalam pertemuan itu membuahkan hasil maka perkara dapat dihentikan dan kedua orang yang berperkara melakukan perdamaian di depan tetuha kampung. Namun, apabila tidak ada permufakatan maka tetuha kampung membuatkan surat dakwaan (gugatan) untuk orang yang mendakwa dan surat jawaban untuk orang yang didakwa (tergugat). Surat dakwaan dan surat gugutan dibawa ke meja pengadilan. Surat dakwaan dan gugatan menjadi dasar seorang hakim dalam memutuskan perkara. Pada perkara 14 ini dikatakan bahwa hakim tidak diperbolehkan memproses atau melanjutkan perkara yang tidak lengkap. Perkara yang lengkap adalah perkara yang disertai dengan surat dakwaan dan surat jawaban.

Perkara 15 menjelaskan tentang hak jawab seorang terdakwa dan tentang kekuasaan seorang hakim. Seorang terdakwa diberikan hak menjawab terhadap surat gugatan namun hak menjawab itu hanya diberikan dalam waktu paling lama lima belas hari. Hal ini berarti tidak akan ada perkara yang berlama-lama mengendap di pengadilan. Apabila selama lima belas hari orang yang digugat tidak mampu menjawab surat gugatan maka berarti orang yang digugat itu tidak dapat menunjukkan bukti-bukti kekuatan hukumnya. Dengan dasar pemikiran ini maka hakim segera memutuskan perkara dengan dasar surat gugatan dari orang yang menggugat. 
Perkara 19 menyiratkan bahwa hukum berlaku kepada siapa saja. Frase bertagih kapada raja-raja atau mantri-mantri, atawa panakawan (menagih utang atau janji kepada raja-raja muda atau mantri-mantri, atau panakawan) bermakna bahwa hukum berlaku juga kepada kalangan istana. Adalah hal yang mungkin terjadi rajaraja muda (anak-anak raja dan saudarasaudara raja) dan kalangan istana lainnya bertransaksi jual beli dan lainnya dengan rakyat. Rakyat dipersilakan datang ke istana menyampaikan surat tagihan jual beli dan urusan perniagaan lainnya asalkan kedatangan mereka itu disertai dengan surat hakim. Perkara ini juga menjelaskan bahwa kekuasaan hakim sangat luas dan sangat kuat.

Perkara 24 berisi petunjuk raja kepada hakim. Hakim diminta membuat tarikh dakwaan dan jawaban tepat pada saat seseorang menyerahkan surat dakwaan dan atau jawaban. Selanjutnya, hakim diminta mempelajari surat-surat itu. Baik hakim, penggugat, dan orang yang digugat, dapat mendatangkan saksi-saksi. Penggugat dan atau tergugat diberikan waktu satu bulan untuk menghadirkan saksi ke pengadilan. Setelah waktu satu bulan, hakim diperintahkan untuk memutuskan perkaranya. Saksi yang didatangkan melebihi satu bulan atau setelah perkara diputuskan tidak dapat mempengaruhi atau mengubah putusan yang telah dijatuhkan oleh hakim.

\section{Perkara Hukum Penguasaan Tanah}

Ada enam perkara yang berhubungan dengan hukum penguasaan tanah, yakni perkara 17, 23, 26, 27, 28, dan 29.

Perkara 17 adalah perkara yang mengharuskan agar seseorang melaporkan kepada hakim apabila mau melakukan jual-beli, gadai-menggadai, dan pinjammeminjam tanah persawahan atau perkebunan. Selanjutnya, hakim membuat surat jual-beli, surat gadai, atau surat pinjammeminjam tanah. Semua surat itu di simpan dan dicatat di dalam buku besar. Surat tanah dibuat dalam dua rangkap, satu rangkap untuk pemilik tanah dan satu rangkap lagi disimpan oleh hakim. Pencatatan atau pengadministrasian ini rupanya sudah dianggap penting walaupun tanah pada masa itu masih terhampar luas. Pencatatan tanah ini adalah untuk menghindari terjadinya sengketa tanah di kemudian hari di samping adanya kepastian kepemilikan atas tanah itu.

Perkara 23 menyatakan bahwa apabila penjualan tanah telah terjadi dua puluh tahun atau lebih maka tuntut-menuntut oleh ahli waris sudah tidak diperbolehkan. Diperintahkan juga kepada hakim agar tidak melayani gugatan ahli waris terhadap tanah warisan yang dua puluh tahun atau lebih telah terjual. Ahli waris, walaupun memiliki bukti dan saksi yang membenarkan gugatannya, dianggap tidak patut menuntut tanah itu lagi karena peristiwa jual beli telah lama terjadi.

Perkara 26 berisi perihal tanah persawahan dan atau ladang yang sudah dijual atau sudah dibagi kepada ahli waris oleh orang tua. Penjualan tanah dan atau pembagian warisan itu sudah menjadi kabar-berita yang diketahui oleh masyarakat luas. Setelah sepuluh tahun atau lebih, orang yang menjual dan orang yang membeli tanah itu meninggal dunia. Dengan demikian, tanah tersebut jatuh ke tangan ahli waris si pembeli. Anak cucu yang menjual tanah tidak boleh menggugat karena ingin memiliki tanah itu lagi. Terlebih lagi peristiwa jual-beli itu diketahui oleh saksi-saki yang masih hidup. Pasal ini menyiratkan bahwa peristiwa jual-beli yang telah lama terjadi (sepuluh tahun lebih) dan orang yang melakukan jual-beli itu kedua-duanya telah meninggal dunia ada kemungkinan ahli waris yang menjual menggugat ingin memiliki kembali tanah yang telah terjual itu.

Perkara 27 berisi tentang sengketa tanah yang diperkarakan di dalam sidang pengadilan. Seseorang menuduh bahwa 
tanahnya telah digarap oleh orang lain, sedangkan orang lain yang dituduh tidak menerima tuduhan itu. Untuk memperoleh kepastian hak milik menurut hukum maka tuduhan ini harus dibawa dan diselesaikan di pengadilan. Dalam persidangan, salah seorang dinyatakan sebagai pemilik sah atas tanah yang disengketakan. Menurut perkara 27, apabila yang memenangkan perkara di pengadilan adalah orang yang menggugat (penggugat) maka si penggugat yang menang berperkara itu tidak boleh menuntut sewa tanah selama tanah itu berada di tangan lawannya berperkara.

Pasal 28 menyatakan bahwa penduduk kampung Halabiu atau penduduk kampung Negara atau penduduk kampung mana saja tidak boleh melarang seseorang yang ingin menggarap tanah untuk persawahan atau perkebunan, asalkan tanah itu belum ada pemiliknya. Tanah persawahan atau perkebunan yang tidak dipelihara berarti telah menjadi tanah yang tidak bertuan sehingga siapapun boleh memanfaatkan tanah itu. Dalam pasal 28 ini disebut penduduk kampung Halabiu dan Negara sebagai contoh. Kampung Halabiu dan kampung Negara adalah dua kampung yang sangat terkenal di kawasan Banjar. Kampung Halabiu terkenal sebagai kampung para peniaga kain yang kaya dan menjajakan perniagaannya ke pelbagai pelosok tanah Banjar. Kampung Negara terkenal sebagai kampung para pengusaha dan peniaga alat-alat pertukangan dan persawahan seperti cangkul, parang, gergaji, dan lain-lain. Tidak hanya mampu membuat alat-alat pertukangan dan persawahan, orang Negara juga mampu membuat perahu yang berukuran besar yang dapat membawa barang-barang perniagaan ke kampung-kampung lain yang jauh. Dengan menyebut dua nama kampung yang tersohor ini, diharapkan perkara ini benar-benar mendapat perhatian seluruh masyarakat.
Perkara 29 menegaskan bahwa tanah yang tidak tergarap selama dua musim akan hilang hak kepemilikan seseorang atas tanah itu. Hal ini berarti, tanah harus dipelihara secara baik agar bisa menghasilkan buah-buahan atau lainnya. Dua musim artinya dua kali mengetam padi atau kurang lebih dua tahun. Tanah yang bertuan harus terlihat dengan jelas tanamtanaman, galangan (alur tanah yang ditinggikan memanjang yang biasa digunakan sebagai batas tanah atau untuk menanam tanam-tanaman), dan sungai yang bersih karena dipelihara oleh pemiliknya.

\section{Perkara Peraturan Peralihan}

UUSA, seperti halnya undang-undang sekarang, juga berisi peraturan peralihan. Peraturan peralihan adalah bagian dari undang-undang yang berisi kemungkinan terjadinya perubahan undang-undang. Peraturan peralihan dalam UUSA termuat pada perkara 16.

Dalam undang-undang modern, pasal yang berisi tentang kemungkinan perubahan undang-undang disebut Peraturan Peralihan. Apabila dalam undang-undang modern Peraturan Peralihan diletakkan pada akhir pasal, dalam UUSA pasal ini diletakkan di tengah-tengah pasal (Perkara 16).

Ada 3 hal yang bicarakan dalam Perkara 16 yakni (i) perkara atau peraturan yang telah ada sebelum Sultan Adam harus diterima atau tidak diperbolehkan dibabak (dirombak) lagi, (ii) perkara atau peraturan yang tertuang dalam UUSA boleh dirombak apabila ternyata isi undang-undang itu kelihatan jelas kesalahannya, (iii) yang berhak merombak UUSA adalah hakim.

Makna penting yang terdapat dalam Perkara 16 ini adalah bahwa UUSA hanyalah berisi tambahan dan penguatan terhadap peraturan yang dibuat oleh para sultan sebelumnya. Apabila peraturan atau undang-undang zaman sebelum Sultan Adam belum tertulis maka pada 
masa Sultan Adam undang-undang itu diungkapkan dalam bentuk tertulis sesuai dengan kemajuan zaman. Sultan menganggap semua aturan yang ada sebelumnya merupakan aturan yang baku dan tidak perlu dirombak lagi. Berbeda dengan UUSA yang dibuat oleh Sultan Adam, segala perkara dapat dirombak oleh hakim apabila ternyata terdapat kekeliruan yang nyata.

\section{SIMPULAN}

Kelahiran UUSA dilatarbelakangi oleh perbedaan pendapat para ulama Banjar tentang aliran dan atau mazhab dalam agama Islam. Satu pihak, Syekh Muhammad Arsyad Al-Banjari, seorang ulama yang mendapat dukungan Sultan, menyebut aliran yang didakwahkannya sebagai aliran ahlusunahwaljamaah dan amalan tarikat samaniyah. Di pihak lain, Syekh Abdul Hamid Abulung, seorang ulama yang tidak mendapat dukungan Sultan, dianggap sebagai aliran ahlal albidaah dan amalan tarikat wahdatul wujud. Ahlal albidaah (ahli bid'ah) berarti aliran agama yang dianggap banyak melakukan penyimpangan terhadap ajaran-ajaran Islam. Penganut ahlal albidaah dianggap melakukan peribadatan dan mengamalkan tarikat dengan cara yang berbeda dari cara yang dicontohkan oleh Rasulullah, sehingga secara otomotis juga bertentangan dengan Alquran.

Pertarungan antara Syekh Arsyad AlBanjari dan Syekh Abdul Hamid Abulung berakhir dengan munculnya fatwa Syekh Arsyad Al-Banjari yang menyatakan bahwa ajaran Syekh Abdul Hamid Abulung adalah aliran sesat. Dengan dasar fatwa ini, Sultan menjatuhkan hukum mati kepada Syekh Abdul Hamid Abulung. Pertarungan dua aliran atau mazhab ulama seperti ini sebelumnya juga pernah terjadi di Aceh antara Hamzah Fansyuri dan Syekh Nuruddin ar-Raniri, seorang ulama kesultanan Aceh. Pertarungan kedua ulama di Aceh ini berakibat dengan pembakaran terhadap buku-buku karangan Hamzah Fansuri (Parnickel, 1995; Haryadi, 2012).

Walaupun Syekh Abdul Hamid Abulung sudah dihukum mati, sisa-sisa pengikutnya ditengarai masih ada. Agar aliran yang dianggap sesat tidak dapat tumbuh kembali Sultan Adam membuat undangundang (UUSA) yang keseluruhan isinya berupa pengawasan terhadap aliran yang dianggap sesat.

Undang-Undang dianggap sebagai pelaksanaan hukum Tuhan. Dalam Perkara 31 dituliskan, “... kalau ada jang anggan dan tiada maasi hoekoem Allah Taala jang dihukumkan oleh hakim jaitoe sakalian lalawangan dan loerahnja dan mantrinja koesoeroeh mangarasakan hoekoem itu... (... apabila ada yang segan dan tidak menurut hukum Allah yang dijatuhkan oleh hakim maka semua Lalawangan, dan Lurahnya, dan Mantrinya saya minta ikut menguatkan hukum yang telah dijatuhkan oleh hakim itu.)" Karena menganggap bahwa undang-undang sebagai hukum Tuhan, ulama menjadi unsur atau bagian penting dalam kerajaan. Ulama tidak saja memimpin upacara-upacara keagamaan, tetapi lebih dari itu, yakni menjadi penasihat raja dalam mengambil keputusan. Dalam perkara 31 disebutkan peran ulama Hadji Djamaloedin yang menjadi "narasumber" penyusunan UUSA. Haji Djamaloedin (anak Syekh Muhammad Arsyad Al-Banjari) adalah seorang ulama Banjar pada masa Sultan Adam.

Berdasarkan uraian di atas dapat disimpulkan bahwa Kerajaan Banjar pada masa Sultan Adam adalah sebuah negara teokrasi. Dalam negara teokrasi, raja menganggap dirinya sebagai pelaksana hukum Tuhan. Agar pelaksanaan hukum Tuhan dapat dilaksanakan dengan baik, raja meminta para ulama terlibat langsung dalam pemerintahan. Fatwa ulama wajib dilaksanakan, seperti fatwa Syekh Arsyad Al-Banjari yang menyatakan Syekh Abdul Hamid Abulung membawa ajaran aliran 
sesat dan dihukum mati. Dengan dasar ini, tanpa keraguan, raja melaksanakan keputusan fatwa itu.

Mazhab atau organisasi keagamaan yang dianggap benar menurut UUSA adalah ahlusunah waljamaah atau Mazhab Imam Syafii. UUSA dianggap sebagai undang-undang yang mampu menyempurnakan agama dan iktikad dan menjadi pegangan para hakim dalam memutuskan perkara. Di samping itu, UUSA menjadi alat untuk mengawasi aliran yang dianggap sesat dan sebagai bentuk perlawanan (counter) terhadap mazhab yang lain.

\section{UCAPAN TERIMA KASIH}

Ucapan terimakasih disampaikan kepada teman sejawat yang telah berkenan menjadi mitra diskusi dalam pemahaman permasalahan dalam artikel ini. Selanjutnya ucapan terimaksih diucapkan kepada reviewer yang telah membaca, mengoreksi dan memberi masukan terhadap artikel ini.

\section{DAFTAR PUSTAKA}

Halidi, Yusuf. 1980. Ulama Besar Kalimantan Syekh Muhammad Arsyad Al Banjari. Banjarmasin: Yayasan Syekh Muhammad Arsyad Al Banjari.

Hamzah, Zaitul Azma Zainon \& Ahmad Fuad Mat Hassan. 2011. Bahasa dan Pemikiran dalam Peribahasa Melayu. GEMA Online ${ }^{T M}$ Journal of Language Studies, 11(3), 31-51.

Haryadi. 2012. Sufisme dalam Syair Hamzah Fansuri. Litera Jurnal Penelitian Bahasa, Sastra, dan Pengajarannya, Volume 11, 243-255.

Ideham, M. Suriansyah, Sjarifuddin, Gazali Usman, M. Zainal Arifin Anis, \& Wajidi. 2003. Sejarah Banjar. Banjarmasin: Badan Penelitian dan Pengembangan Daerah Propinsi Kalimantan Selatan.

Jamalie, Zulfa. 2012. Sultan Adam alWatsiq Billah dan Sejarah Penerapan Islam di Tanah Banjar. Al Jami Jurnal
Ilmiah Keagamaan, Pendidikan, dan Dakwah , 8, 121-132.

Kaelan. 2005. Metode Penelitian Kualitatif bidang Filsafat Paradigma bagi Pengembangan Penelitian Interdisipliner Bidang Filsafat, Budaya, Sosial, Semiotika, Sastra, Hukum dan Seni. Yogyakarta: Paradigma.

Kaelan. 2009. Filsafat Bahasa Semiotika dan Hermeneutika. Yogyakarta: Paradigma.

Kawi, Djantera. 2011. Telaah Bahasa Banjar. Banjarbaru: Scripta Cendekia.

Kratz, E.U. 2004. Segi-Segi Karangan Melayu Tradisional. Kuala Lumpur: Dewan Bahasa dan Pustaka Kuala Lumpur.

Kridalaksana, Harimurti. 1993. Kamus Linguistik. Jakarta: Gramedia Pustaka Utama.

Liaw Yock Fang. 1993. Sejarah Kesusastraan Melayu Klasik Jilid 2. Jakata: Erlangga.

Mahali, Saidatul Nornis Hj. \& Mohd. Rasdi Saamah. 2013. Haiwan Sebagai Perlambangan Dalam Peribahasa Orang Semai. GEMA Online ${ }^{T M}$ Journal of Language Studies , 13(1), 83-98.

Newton, K.M. 1994. Menafsirkan Teks Pengantar Kritis kepada Teori dan Praktik Penafsiran Sastra. (M. Soelistia, Trans.) Semarang: IKIP Semarang Press.

Parnickel, B. 1995. Perkembangan Sastera Nusantara Serumpun (Abad ke-7 - ke19. Kuala Lumpur: Dewan Bahasa dan Pustaka Kementerian Pendidikan Malaysia.

Ratna, Nyoman Kutha. 2004. Teori, Metode, dan Teknik Penelitian Sastra. Yogyakarta: Pustaka Pelajar.

Ricoeur, P. 2012. Hermeneutika Ilmu Sosial. (Muhammad Syukri, Trans.) Bantul: Kreasi Wacana.

Sudjiman, Panuti. 1990. Kamus Istilah Sastra. Jakarta: Universitas Indonesia (UI-Press).

Suryani NS, Elis. 2012. Filologi. Bogor: Ghalia Indonesia.

Zaidan, Abdul Rozak, Anita K. Rustapa \& Hani'ah. 2007. Kamus Istilah Sastra. Jakarta: Balai Pustaka. 